\title{
PENGARUH KEPEMILIKAN MANAJERIAL DAN UKURAN PERUSAHAAN TERHADAP NILAI PERUSAHAAN PADA INDUSTRI MANUFAKTUR YANG TERDAFTAR DI BURSAEFEK INDONESIA (BEI)
}

\author{
ANITA RAHMAWATI \\ DJAYANI NURDIN \\ CICI RIYANTI K. BIDIN \\ Jurusan Manajemen, Fakultas Ekonomi, Universitas Tadulako \\ email: nita.akkas@yahoo.co.id
}

\begin{abstract}
The value of the company reflects investor's perception on the success of a company that are often associated with stock prices. High stock price influences the value of the company's and will impress the market of company's current and future performances. The purpose of this study is to determine the influence of managerial ownership and the size of the company to the value of the company in the manufacturing industry listed on the Indonesia Stock Exchange (BEI) in the period of 2011-2012. Population consists of manufacturing industry with managerial ownership whose shares are listed and actively traded on the Indonesia Stock Exchange (BEI) in the period 2011-2012. The data in this research is secondary data obtained from the Indonesia Stock Exchange. Sampling method is purposive sampling. The number of samples taken based on the criteria is 20 companies. Data analysis method is multiple linear regression analysis. The test results show that managerial ownership and firm size simultaneously have significant influence on the value of manufacturing companies in the Indonesia Stock Exchange. Partially, managerial ownership and the size of the company significantly have negative influence on the value of companies in the manufacturing industry in the Indonesia Stock Exchange.
\end{abstract}

Keywords: corporate values, managerial ownership, firm size.

\begin{abstract}
Abstrak
Nilai perusahaan merupakan persepsi investor terhadap tingkat keberhasilan perusahaan yang sering dikaitkan dengan harga saham, harga saham yang tinggi membuat nilai perusahaan juga tinggi, nilai perusahaan yang tinggi akan membuat pasar percaya tidak hanya pada kinerja perusahaan saat ini namun juga pada prospek perusahaan di masa depan. Tujuan penelitian ini adalah untuk mengetahui pengaruh kepemilikan manajerial dan ukuran perusahaan terhadap nilai perusahaan pada industrimanufaktur yang terdaftar di Bursa Efek Indonesia (BEI) periode tahun 2011-2012. Populasi dalam penelitian ini adalah industri manufaktur dengan kepemilikan manajerial yang sahamnya terdaftar dan aktif diperdagangkan di Bursa Efek Indonesia (BEI) periode 20112012.Data yang digunakan dalam penelitian ini adalah data sekunder yang diperoleh dari Bursa Efek Indonesia. Metode penarikan sampel yang digunakan adalah purposive sampling.Banyaknya sampel yang diambil yaitu sesuai dengan kriteria-kriteria yang telah ditentukan sebanyak 20 perusahaan. Metode analisis data yang digunakan pada penelitian ini adalah analisis regresi linear berganda. Hasil pengujian ini menemukan bahwa secara simultan variabel kepemilikan manajerial dan ukuran perusahaan berpengaruh signifikan terhadap nilai perusahaan industri manufaktur di Bursa Efek Indonesia.Secara parsial variabel kepemilikan manajerial dan ukuran perusahaan berpengaruh negatif dan signifikan terhadap nilai perusahaan pada industri manufaktur di Bursa Efek Indonesia.
\end{abstract}

Kata Kunci: nilai perusahaan, kepemilikan manajerial dan ukuran perusahaan.

\section{PENDAHULUAN}

Menghadapi era industrialisasi yang semakin kompetitif sekarang ini, setiap perusahaan harus meningkatkan daya saing secara terus-menerus.dimanapersaingan yang semakin meningkat baik dipasar domestik maupun dipasar internasional, menuntut perusahaan untuk dapat mempertahankan atau memperoleh keuntungan kompetitif dengan cara memperhatikan dengan penuh pada kegiatan 
operasional dan finansial perusahaan.Salahsatu upaya yangdilakukan oleh para pemilik dan pemegang saham adalah dengan memperkerjakan tenaga ahli atau profesional untuk di posisikan sebagai manajer ataupun komisaris untuk mengelola perusahaan.

Perusahaan didirikan dengan tujuan untuk memakmurkan pemilik perusahaan atau pemegang saham. Tujuan ini dapat diwujudkan dengan memaksimumkan nilai perusahaan dengan asumsi bahwa pemilik perusahaan atau pemegang saham akan makmur jika kekayaanya meningkat.

Menurut Hougen dalam Utomo (2000) nilai perusahaan dapat didefinisikan dari harga sahamnya. Short dan Keasy dalam Utomo (2000) menyatakan bahwa nilai pasar suatu saham dapat dipergunakan sebagai tolak ukur nilai perusahaan yang sebenarnya. Hal tersebut menurut Himmelberg dalam Utomo (2000) disebabkan karena harga pasar saham yang mengandung harapan mengenai masa depan suatu perusahaan. Secara sederhana definisi saham yaitu surat berharga sebagai bukti penyertaan atau kepemilikan individu maupun institusi dalam suatu perusahaan. Dimana menurut Short dan Keasy dalam Utomo (2000) nilai perusahaan ini menggunakan tolak ukur nilai pasar suatu saham.

Kepemilikan manajerial adalah situasi dimana manajer memiliki saham perusahaan atau dengan kata lain manajer tersebut sekaligus sebagai pemegang saham perusahaan (Cristiawan dan Tarigan, 2007). Konflik keagenan bisa dikurangi bila manajer yang memiliki saham perusahaan tertentu akan berbeda dengan manajer yang murni sebagai manajer. Manajer yang sekaligus pemegang saham akan berusaha meningkatkan nilai perusahaan, karena dengan meningkatnya nilai perusahaan maka nilai kekayaannya sebagai pemegang saham akan meningkat pula. Dengan kepemilikan manajerial, seorang manajer yang sekaligus pemegang saham tidak ingin perusahaan mengalami kebangkrutan. Kebangkrutan usaha akan merugikan manajer karena kehilangan insentif dan pemegang saham akan kehilangan returnbahkan dana yang di investasikan.

Salah satu cara untuk mengatasinya adalah kepemilikan manajerial untuk menyamakan kepentingan principal dan agent. Kepemilikan manajerial (managerial ownership) adalah tingkat kepemilikan saham pihak manajemen secara aktif ikut dalam pengambilan keputusan, misalnya direktur dan komisaris (Wahidahwati, 2002).Kepemilikan manajerial ini diukur dengan porsi saham yang dimiliki perusahaan pada akhir tahun dan dinyatakan dalam prentase.

Perusahaan besar dapat mengakses pasar modal.Kemudahan akses terhadap berbagai sumber daya memungkinkan perusahaan memiliki fleksibilitas dan kemampuan untuk mendapatkan dana. Ukuran perusahaan dapat diartikan sebagai besar kecilnya perusahaan dilihat dari besarnya nilai equity, nilai perusahaan, ataupun hasil nilai aktiva dari suatu persahaan (Bambang Riyanto, 2013). Besar kecilnya ukuran suatu perusahaan akan berpengaruh terhadap struktur modal, semakin besar perusahaan maka akan semakin besar pula dana yang dibutuhkan perusahaan untuk melakukan investasi. Semakin besar ukuran suatu perusahaan, maka kecenderungan menggunakan modal asing juga semakin besar. Hal ini disebabkan karena perusahaan besar membutuhkan dana yang besar pula untuk menunjang operasionalnya, dan salah satu alternatif pemenuhannya adalah dengan modal asing apabila modal sendiri tidak mencukupi.

Berdasarkan latar belakang di atas, maka permasalahan yang diangkat adalah:

1. ApakahKepemilikan manajerialdan ukuran perusahaan secara simultan berpengaruh terhadap nilai perusahaan pada industri manufaktur yang terdaftar di Bursa Efek Indonesia (BEI)?

2. Apakah Kepemilikan manajerialsecara parsial berpengaruh terhadap nilai perusahaan pada industri manufaktur yang terdaftar di Bursa Efek Indonesia (BEI)?

3. Apakah Ukuran perusahaan secara parsial berpengaruh terhadap nilai perusahaan pada industri manufaktur yang terdaftar di Bursa Efek Indonesia (BEI)? 


\section{KAJIAN LITERATUR DAN PENGEMBANGAN HIPOTESIS}

Manufaktur merupakan suatu cabang industri yang mengaplikasikan peralatan dan suatu medium proses untuk transformasi bahan mentah menjadi barang jadi untuk dijual.Upaya ini melibatkan semua proses antara yang dibutuhkan untuk produksi dan integrasi komponen-komponen suatu produk, Manufaktur dapat di definisikan dari dua sisi yaitu Teknologi dan Ekonomi. Dari sisi Teknologi manufaktur merupakan aplikasi dari proses fisika dan kimia untuk mengubah geometri, property dan atau tampilan material awal menjadi part atau produk, manufaktur termasuk juga perakitan beberapa part menjadi produk. Proses manufaktur melibatkan kombinasi dari machinery, tools, power dan tenaga kerja. Sedangkan Dari sisi Ekonomi, manufaktur merupakan transformasi material menjadi item yang mempunyai penambahan nilai (value) melalui suatu proses atau perakitan.Struktur Modal adalah bauran atau perpaduan dari utang, saham preferen, saham biasa yang dikehendaki perusahaan dalam struktur modalnya. (Weston dan Brigham, 2005),

Kepemilikan manajerial merupakan suatu keadaan dimana pihak pengelola perusahaan juga mempunyai bagian kepemilikan perusahaan dalam bentuk saham (Insider Ownersip) . Kepemilikan manajerial merupakan suatu hal yang menarik jika dikaitkan dengan teori keagenan, dimana principal merupakan pihak yang memberikan mandate kepada manajer yang bertindak sebagai agen sekaligus pemegang saham. Kepemilikan manajerial ini merupakan informasi penting bagi pengguna laporan keuangan.Oleh karena itu, kepemilikan manajerial ini dimuat dalam laporan keuangan yang dinyatakan dalam bentuk persentase kepemilikan saham oleh manajer atau Insider Ownership.

Suatu perusahaan bisa saja dikatakan sebagai perusahaan besar, jika kekayaan yang dimilikinya besar. Demikian pula sebaliknya, perusahaan tersebut dikatakan kecil, jika kekayaan yang dimilikinya adalah sedikit. Menurut Sujoko dan Soebiantoro (2007) ukuran perusahaan merupakan cerminan besar kecilnya perusahaan yang nampak dalam nilai total aktiva perusahaan pada neraca akhir tahun. Taswan (2003) menyatakan bahwa perusahaan besar umumnya memiliki fleksibilitas dan aksebilitas yang tinggi dalam masalah pendanaan di pasar modal.

Pada penelitian ini akan digunakan total aktiva untuk mengukur ukuran perusahaan karena nilai aktiva relatif lebih stabil dibandingkan penjualan (Sulistiono, 2010). Ukuran perusahaan menunjukkan besar kecilnya perusahaan yang dapat dilihat dari besar kecilnya total aktiva yang dimiliki. Jadi salah satu tolak ukur yang menunjukkan besar kecilnya perusahaan adalah total aktiva dari perusahaan tersebut. Nilai perusahaan merupakan persepsi investor terhadap tingkat keberhasilan perusahaan yang sering dikaitkan dengan harga saham (Sujoko dan Soebiantoro (2007). Harga saham yang tinggi membuat nilai perusahaan juga tinggi. Nilai perusahaan yang tinggi akan membuat pasar percaya tidak hanya pada kinerja perusahaan saat ini namun juga pada prospek perusahaan di masa depan.

Menurut Christiawan dan Tarigan (2007), ada beberapa konsep yang menjelaskan nilai perusahaan yaitu nilai nominal, nilai intrinsik, nilai likuiditas, nilai buku, dan nilai pasar. Nilai nominal adalah nilai yang tercantum secara formal dalam anggaran dasar perseroan.Nilai likuiditas adalah nilai jual seluruh asset perusahaan setelah dikurangi semua kewajiban yang harus dipenuhi.Nilai buku adalah nilai perusahaan yang dihitung dengan dasar konsep akuntansi. Nilai pasar adalah harga yang terjadi dari proses tawar-menawar di pasar saham sedangkan konsep yang paling representatif untuk menentukan nilai suatu perusahaan adalah konsep intrinsik. Nilai perusahaan dalam konsep nilai intrinsik ini bukan sekedar harga dari sekumpulan nilai asset, melainkan nilai perusahaan sebagai entitas bisnis yang memiliki kemampuan menghasilkan dikemudian hari.

Berdasarkan uraian-uraian sebelumnya maka dapat dirumuskan hipotesis penelitian ini sebagai berikut: 
H1 : Kepemilikan manajerialdan ukuran perusahaan secara simultan berpengaruh terhadap nilai perusahaan pada industri manufaktur yang terdaftar di Bursa Efek Indonesia (BEI).

$\mathrm{H} 2$ : Kepemilikan manajerial secara parsial berpengaruh terhadap nilai perusahaan pada industri manufaktur yang terdaftar di Bursa Efek Indonesia (BEI).

H3 : Ukuran perusahaan secara parsial berpengaruh terhadap nilai perusahaan pada industri manufaktur yang terdaftar di Bursa Efek Indonesia (BEI).

\section{METODE PENELITIAN}

Menjawab permasalahan dan hipotesis penelitian ini, peneliti menggunakan metode penelitian uji hipotesis, yang menguji pengaruh kepemilikan manajerial dan ukuran perusahaan terhadap nilai perusahaan. Menurut Sekaran (2000:48), penelitian uji hipotesis adalah untuk menguji pengaruh atau hubungan dua atau variabel dan juga untuk menguji perbedaan dua atau lebih variabel.

Berdasarkan permasalahan dan hipotesis yang akan diuji, maka jenis data yang digunakan dalam penelitian ini adalah berupa data sekunder yaitu data informasi keuangan yang tersaji dalam bentuk deskripsi tentang kondisi keuangan suatu perusahaan. Data sekunder adalah data yang dikumpulkan oleh lembaga pengumpulan data dan dipublikasikan kepada masyarakat pengguna data (Kuncoro, 2009:148).Data sekunder yang digunakan adalah informasi keuangan dari Indonesian Capital Market Directory 2011, dan 2012.ICMD merupakan ringkasan data keuangan, pemegang saham, alamat terbaru, dan perkembangan saham dari seluruh emiten dipasar modal yang diterbitkan oleh ECFIN (Economic and Finance Institute). Data yang dipergunakan meliputi rasio kepemilikan manajerial, ukuran perusahaan, dan nilai perusahaan. Metode analisis data yang digunakan pada penelitian ini adalah analisis regresi linear berganda.

\section{HASIL DAN PEMBAHASAN}

1. Pengaruh Kepemilikan Manajerial $\left(\mathrm{X}_{1}\right)$ terhadap Nilai Perusahaan $(\mathrm{Y})$. Hasil pengujian menunjukkan nilai variabel kepemilikan manajerial diperoleh nilai t hitung sebesar -1.932 dengan taraf signifikansi 0.061 lebih kecil dari 0.05 . Dengan demikian $\mathrm{H}_{0}$ diterima. Hal ini menunjukkan bahwa secara parsial variabel Kepemilikan Manajerial mempunyai pengaruh negatif terhadap Nilai Perusahaan, ini terlihat dari hasil koefisien regresi yang bernilai negatif. Hal ini terlihat pada rendahnya kepemilikan saham oleh manajerial pada industri manufaktur yang terdaftar di Bursa Efek Indonesia. Rendahnya kepemilikan saham oleh manajerial tersebut disebabkan kurangnya kepercayaan pasar terhadap manajer. Dimana segala sesuatu yang dilakukan oleh manajer, pasar akan bereaksi atau belaku negatif terhadap keputusan manajer.

2. Pengaruh Ukuran Perusahaan $\left(\mathrm{X}_{2}\right)$ Nilai Perusahaan $(\mathrm{Y})$. Hasil pengujian menunjukkan nilai variabel Ukuran Perusahaan diperoleh nilai t hitung sebesar -5.332 dengan taraf signifikansi 0.5 lebih kecil dari 0.000. Dengan demikian $\mathrm{H}_{0}$ diterima. Hal ini membuktikan bahwa variabel Ukuran Perusahaan secara negatif mempengaruhi Nilai Perusahaan industri manufaktur di Bursa Efek Indonesia yang ditunjukkan dengan koefisien regresi yang negatif. Hal ini disebabkan karena pada industri manufaktur memilki aset yang besar namun aset tersebut merupakan aset yang tidak produktif, dimana hal tersebut terlihat pada jumlah aset tidak lancar yang besar sehingga ukuran perusahaan memberikan pengaruh turunnya nilai perusahaan pada sebagian besar industri manufaktur di Bursa Efek Indonesia.

\section{KESIMPULAN DAN SARAN}

\section{Kesimpulan}

Adapun hasil penelitian dapat disimpulkan sebagai berikut:

1. Kepemilikan Manajerial dan Ukuran Perusahaan secara simultan berpengaruh signifikan terhadap Nilai Perusahaan Industri Manufaktur di Bursa Efek Indonesia. 
2. Kepemilikan Manajerial secara parsial berpengaruh signifikan terhadap Nilai Perusahaan Industri Manufaktur di Bursa Efek Indonesia.

3. Ukuran Perusahaan secara parsial berpengaruh signifikan terhadap Nilai Perusahaan Industri Manufaktur di Bursa Efek Indonesia.

\section{Saran}

1. Bagi penelitian selanjutnya, dianjurkan sebaiknya menambah variabel-variabel lain selain variabel yang digunakan dalam penelitian ini yang mungkin berpengaruh terhadap nilai perusahaan, seperti kebijakan hutang, kebijakan diveden, struktur modal, pertumbuhan perusahaan, profitabilitas, keputusan pendanaan, keputusan investasi. Serta menambah rentang waktu penelitian karena dalam penelitian ini hanya mengambil rentang waktu yang cukup singkat.

2. Bagi perusahaan ataupun manajer serta pengelola perusahaan yang akan menetapkan kebijakankebijakan perusahaan dimasa yang akan datang, sebaiknya mempertimbangkan kebijakan apa saja yang berkaitan dengan variabel-veriabel dalam meningkatkan nilai perusahaan, sehingga keputusan yang diambil oleh para manajer atau pun para pengelola adalah keputusan yang terbaik untuk perusahaan dimasa yang akan datang serta dapat meningkatkan nilai perusahaan tersebut.

\section{REFERENSI}

Agnes. (2010). Pengaruh Kepemilikan Manajerial, Struktur Modal, dan Ukuran Perusahaan Terhadap Nilai Perusahaan. Jurnal

Antari, Praidy Prati Ayu Dewa \& Dana, Made I. (2011). Pengaruh Struktur Modal, Kepemilikan Manajerial, dan Kinerja Keuangan terhadap Nilai Perusahaan. Jurnal

Brigham, Eguene F \& Houston, Joel. (2010)., Dasar-Dasar Manajemen Keuangan, Salemba Empat, Jakarta

Brigham, E,F \& Weston, J,F. 2005. Dasar-Dasar Manajemen Keuangan, Edisi Kesembilan, Jilid 2, Penerbit Erlangga, Jakarta.

Christiawan, Yulius Jogi \& Josua Tarigan. (2007). Kepemilikan Manajerial, Kebijakan Hutang, Kinerja \& Nilai Perusahaan.

Fadli, Warzuqni Arli (2010). Faktor-Faktor Yang Mempengaruhi Struktur Modal Pada Perusahaan Manufaktur Go Public Di Bursa Efek Indonesia Tahun 2005-2007. Skripsi,

Fahmi, Irham. (2013). Pengantar Manajemen Keuangan, Alfabeta, Bandung

Ghozali, Imam. (2011). Aplikasi Analisis Multivariate dengan Program IBM SPSS 19. Edisi Lima. Semarang: Universitas Diponegoro

Jimmi, Farid. (2008). Pengaruh Hutang dan Kepemilikan Manajerial terhadap Nilai Perusahaan pada Perusahaan Manufaktur. Jurnal Akuntansi FE Unsil.Vol 3 No.1, 2008.

Keown, K., M. Petty. And Scoutt. (2004). Manajemen Keuangan 1 dan 2. Edisi 9 (terjemahan). Kuncoro, Mudrajad, 2009, Metode Riset untuk Bisnis \& Ekonomi, Edisi Ketiga, Erlangga, Jakarta. Jakarta.

Mahadwarta. (2012). Pengaruh Kepemilikan Manajerial Dan Investasi Perusahaan Terhadap Nilai Perusahaan. Skripsi

Mutiya, Ayu. (2012). Pengaruh Struktur Kepemilikan, Struktur Modal, Dan Ukuran Perusahaan Terhadap Nilai Perusahaan Pada Perusahaan LQ-45 Yang Terdaftar di BEI 20092011.Jurnal

Putra, Andhika Surya (2012). Analisis Pengaruh Ukuran Perusahaan, Kepemilikan Manajerial, Terhadap Kinerja Perusahaan Serta Dampaknya Terhadap Nilai Perusahaan. Jurnal

Rachmawati, Andri. Dan Triatmoko Hanung. (2007). Analisis Faktor-Faktor Yang Mempengaruhi Kualitas Laba dan Nilai Perusahaan.Jurnal

Riyanto Bambang, 2013. Dasar-Dasar Pembelanjaan Perusahaan, Edisi 4, Cetakan Keempat, BPFE. Yogyakarta 
Rahmawati, A.

Sartono, Agus (2012). Manajemen Keuangan Teori dan Aplikasi, Edisi 4, Cetakan Keenam BPFE. Yogyakarta

Sasurya, Aris \& Nadia Asandimitra. (2013). Pengaruh Kepemilikan Manajerial, Keputusan Investasi, Keputusan Pendanaan, Dan Kebijakan Dividen Terhadap Nilai Perusahaan.Jurnal Ilmu Manajemen. Vol 1 Nomor 2.

Sekaran, Uma.( 2015). Metodologi Penelitian Untuk Bisnis. Edisi Keempat, Salemba Empat. Jakarta

Siallagan, Hamonangan dan Mas'ud Mafoedz. (2006). Mekanisme Corporate Governance, Kualitas Laba, dan Nilai Perusahaan, Simposium Nasional Akuntansi 9 Padang.

Soliha, ET. (2002). Pengaruh Kebijakan Hutang Terhadap Nilai Perusahaan Serta Beberapa Faktor Yang Mempengaruhinya.Jurnal Bisnis dan Ekonomi Vol 9, STIE STIKUBANK.

Sugiyono. (2013). Metode Penelitian Bisnis. Alfabeta, Bandung.

Sujoko. \& U, Soebiantoro. 2007. Pengaruh Struktur Kepemilikan Saham, Leverage, Faktor intern dan Faktor ekstern terhadap Nilai Perusahaan. Jurnal Manajemen dan Kewirausahan. Vol. 9. No 1. Maret: 41-48.

Sulistiono. (2010). "Pengaruh Kepemilikan Manajerial, Struktur Modal, dan Ukuran Perusahaan pada Nilai Perusahaan Pada Perusahaan Manufaktur Di BEI. Jurnal

Taswan. (2003). “Analisis Pengaruh Insider Ownership, Kebijakan Hutang, dan Dividen Terhadap Nilai Perusahaan Serta Faktor-Faktor Yang Mempengaruhinya:.Jurnal Ekonomi dan Bisnis, Vol, No.2, 162-181

Utomo, M. Muslim. (2000). Praktek Pengungkapan Sosial Pada Laporan Tahunan Perusahaan Di Indonesia (Studi Perbandingan Antara Perusahaan High Profile \& Low Profile).Simposium Nasional Akuntansi III, IAI

Wahidahwati. (2002). "Pengaruh Kepemilikan Manajerial Institusional Pada Kebijakan Hutang Perusahaan: Sebuah Perspektif Theory Agency". Jurnal Riset Akuntansi Indonesia. 41-45

Weston, Fred, J dan Thomas, E Copeland. (1997). Manajemen Keuangan Jilid 2. Jakarta: Binarupa Aksara

Wiyono, Indriana Lany. (2012). Pengaruh Struktur Kepemilikan, Kebijakan Dividen, Dan Ukuran Perusahaan, Terhadap Nilai Perusahaan Pada Industri Manufaktur Yang Terdaftar DiBursa Efek Indonesia Periode 2009-2011. 